\title{
BEING PSYCHOLOGICALLY ABUSED IS NOT ENOUGH INTO ENDING A RELATIONSHIP
}

\author{
Rui Nunes-Costa ${ }^{1}$ \\ Mafalda Serra \\ Tânia Sousa \\ Ângela Leite \\ Universidade Europeia, Portugal
}

\begin{abstract}
Our aim is to understand the role of the sunk cost effect in intimate abusive relationships. Results of a questionnaire, based on likely scenarios applied to 267 women, show that women in a relationship invest more time/days in a relationship than those who are not in a relationship. Also, an effect of scenario and of relationship status on sunk cost effect were found. Women spend more time in a non-violent scenario; also, they spend more time in a scenario of psychological violence than in one of sexual or physical violence. These results suggest that being in a relationship enhance the likelihood of committing sunk cost effect; prior investments in a relationship acquire more value for individuals in a current relationship where those efforts exist naturally.
\end{abstract}

\section{Keywords}

Sunk cost effect; decision-making; intimate abusive relationship; violence

\section{RESUMO}

O nosso objetivo é compreender o papel do sunk cost effect em relacionamentos íntimos abusivos. Os resultados de um questionário, baseado em cenários prováveis aplicados a 267 mulheres, mostram que os participantes de um relacionamento investem mais tempo/ dias num relacionamento do que quem não está um relacionamento. Além disso, um efeito do cenário e do estatuto do relacionamento no sunk cost effect foi encontrado. As mulheres passam mais tempo mum cenário não violento; além disso, elas permaecem mais tempo num cenário de violência psicológica do que num de violência sexual ou física. Esses resultados sugerem que estar num relacionamento aumenta a probabilidade de sunk cost effect; investimentos anteriores num relacionamento adquirem mais valor para os indivíduos num relacionamento atual, onde esses esforços existem naturalmente.

\section{Palavras-chave}

Sunk cost effect; tomada de decisão; relação íntima abusiva; violência

\footnotetext{
${ }^{1}$ Correspondence about this article should be addressed to Rui Nunes-Costa. Rmail: rui.costa@ universidadeeuropeia.pt
} 


\section{SER ABUSADO PSICOLÓGICAMENTE NÃO É SUFICIENTE PARA FINALIZAR UM RELACIONAMENTO}

\section{Sunk cost effect}

The sunk cost effect takes place when a prior investment of money, effort or time drives to a continuous investment in a failed direction, when the logical action would be to stop investing (Chung \& Cheng, 2018). From an economic perspective, this behavior is irrational because only future costs and benefits (not past) should determine decision making (Feldman \& Wong, 2018). Several theories try to explain the sunk cost effect. (1) The prospect theory

(Kahneman \& Tversky, 1979, 1984; Pachur, Schulte-Mecklenbeck, Murphy, \& Hertwig, 2018), in which value is assigned to gains and losses, tending individuals to value more losses compared with gains, committing more resources into a losing course of action, even after negative outcomes. (2) The self-justification theory (Khoso, Shaikh, Parmar, \& Bashir, 2018; Staw \& Ross, 1987) which states that people are motivated to find justifications for their actions, beliefs and feelings and to convince themselves that it was the only logical and reasonable thing to be done. According to this theory, people are more predisposed to invest in a losing course of action when they are personally responsible for negative past outcomes, i.e., higher personal responsibility for initial decisions leads to higher degree of sunk cost effect. (3) The waste-avoidance theory (Arkes \& Ayton, 1999; Lin \& Chang, 2017), in which avoidance of waste is a motivating factor in people's decision to honor sunk costs by not abandoning a failed course of action. And finally, (4) the self-control science (De Ridder \& Lensvelt-Mulders, 2018; Rachlin, 2000) that teaches how to resist temptations and refuse to act impulsively, since we have a tendency to be influenced by sunk costs. Ali, Zhou, Miller and Ieromonachou (2016) stated that sunk costs has effects on resistance to change, "being trapped in the sunk cost in the domain specific to one's negative schemas may further reinforce the negative schema" (Leahy, 2000, p. 369).

\section{Sunk cost effect and decision making}

Sunk cost effect refers to the impact of sunk costs on decision-making (Haita-Falah, 2017). Rover, Wuerges, Tomazzia and Borba (2009) confirm the relevance of the cognitive bias caused by sunk costs, as they indicate a lower probability of choosing the right answer when these involve sunk costs in the decisions. Yoder, Mancha and Agrawal (2014) found that personal decisions were associated with more bias than decisions made on behalf of others; besides, cultural differences on sunk cost bias were consistent with self-justification theory. Yoder and colleagues (2014) also stated that situations influenced error and perceived behavioral control were effective at predicting sunk cost bias.

Humans are poor decision-makers, not taking account of important information for decision-making and action (O'Mara, 2018). Cognitive biases is a pervasive and universal aspect of human thinking and becomes maladaptive when information gathering is conducted over an extended period (idem). Biases can be adaptive because they solve quickly and efficiently problems arising from information overload, lack of meaning and the need to act fast (Benson, 2017). When a problem needs to be solved rapidly (incomplete information and high degree of ambiguity), and decisions and actions need to be taken, biases will most likely be adaptive (O'Mara, 2018). When a problem is ambiguous (information takes time, extensive deliberative processes involved, outcomes are uncertain), cognitive biases is likely to be present and causes a deviation from an optimal course of action (idem). Tversky and Kahneman (1981) used the concept "'decision frame" to refer to the "decision-maker's conception of the acts, outcomes, and contingencies associated with a particular choice" (p. 45). The decision-maker uses a frame controlled by the formulation of the problem and by the norms, habits, and personal characteristics, namely, age (Löckenhoff, 2017). According to Keeling, Smith, and Fisher (2016), midlife women differ from younger women by transitioning quickly though the stages of change, due to the experience of living with long-term violence, which changes the women's perception towards the violent partner. Most influential decision making theories suggest that people are more prone to decision errors and biases as their mental resources 
become scarce; however, Lee, Keil and Wong (2018) found that a tired mind can help reduce bias escalation.

\section{Sunk cost effect in relationships}

Rego, Arantes and Magalhães (2016) studied the role of the sunk cost effect in committed relationships and found that the likelihood of participants staying in a relationship was higher when money and effort, but not time, had been previously invested in that relationship. In the same study, Rego and colleagues (2016) also found a sunk time effect, that is, participants were willing to invest more time in a relationship in which more time had already been invested. Kim and Son (2009) conceptualized dedication as appreciation for the relationship while constraints, as sunk cost, avoid the loss of investment on the relationship. According to Choua and Hsub (2018) people understand that benefits occur when these outweigh costs; and peolpe perceive investment when investment (sunk) costs outweigh benefits.

"A partner's effort can elicit an implicit sense of commitment to joint action, leading to increased persistence in the face of a temptation to disengage" (Székelya \& Michaela, 2018, p. 41). The sense of commitment to joint action plays an important role in managing one's relationships because a partner's effort investment indicates that the continuation of a situation is likely to be valuable (Heintz et al., 2015).

\section{Decision to leave an abusive relationship}

Intimate partner violence (IPV) is a serious, although preventable, health problem (Centers for Disease Control and Prevention [CDC], 2018), with 10 to 69 percent of women reporting physical assault by an intimate partner at some time in their life (World Health Organization [WHO], 2003). Khaw and Hardesty (2015) showed that leaving an abusive partner is a complex process occurring in stages (not a single isolated event). The earliest stage is often characterized by an abused woman not recognizing or denying the situation, which makes that leaving is not an option (Bermea, Khaw, Hardesty, Rosenbloom, and Salerno, 2017). In the middle stage, she recognizes her situation, tries to cope with the abuse, begins to consider leaving her relationship, and decides to leave (Bermea et al., 2017). In the last stage, she struggles to remain separated from and prevent returning to her abusive partner (Bermea et al., 2017) Lacey, Saunders and Zhang (2011) found that most abused women leave several times their abusive relationships before doing it permanently. A decision to leave an abusive relationship has been reviewed by Strube (1988) and it was found that several factors influence this decision, namely, employment outside the home, length of relationship, child abuse, and number of previous separations. Strube (1988) also found interrelated models that help the understanding of this decision: psychological entrapment, learned helplessness, cost/benefit analysis, and reasoned action. Psychological entrapment is a decision process where individuals keep their commitment to a previously chosen (failed) course of action to justify prior investments (Buchko, Buscher, \& Buchko, 2017). Learned helplessness results of a perceived non-contingency between responses and outcomes that originates the expectation that future responses and outcomes will also be independent (Chung, Choi, \& Du, 2017). Cost/benefit analysis derive from the exchange theory (Liao, McComas, \& Connie Yuan, 2017) that states that relationship decisions are the result of an analysis of the costs and benefits of current relationships compared to those of alternative relationships, suggesting a two-stage decision process. At the first stage, the battered woman decides between the benefits and the costs of the relationship, arriving at a subjective estimate of satisfaction. On a second moment, the satisfaction with the current relationship is compared to the estimated satisfaction with alternatives to the relationship. Fishbein and Ajzen (1975; Sheeran \& Abraham, 2017) proposed the theory of reasoned action which states that thoughtful actions and decisions are directly related to behavioral intentions, that are, in turn, determined by the attitude toward the behavior and the subjective norm. In other words, if an individual believes that a behavior has a high likelihood of resulting in valued outcomes, or avoiding undesirable ones, the intention to perform that behavior will be high. 
The main purpose of the current study is to understand the role of the sunk cost effect in intimate abusive relationships. More specifically, the present study seeks to understand if prior monetary issues, effort and time investment in a relationship will produce the sunk cost effect when there is no violence, when physical violence, psychological violence or sexual violence exist. We hypothesized that existence of episodes of violence in a relationship (physical, psychological or sexual) will be considered as cost to the relationship (Liao et al, 2017), reducing sunk cost effect and willing participants to leave that hypothetical relationship more rapidly.

\section{Procedures}

\section{Methods}

The present study procedures were based on the study "Is there a Sunk Cost Effect in Committed Relationships?" (Rego, Arantes, \& Magalhães, 2016). This study received Institutional Review Board approval and the researchers obtained participant's informed consent.

For the present between-group design research, the sample was non-prababilistic (convenience) and data was collected through an online questionnaire that included sociodemographic questions (age, literacy, marital status, number of children, sexual orientation, whether is currently in a relationship and for how long) and four questions related to the theme: (1) "From 0 to 100 how much longer would you invest in this relationship?" (being 0 - no time, 100 - very long), (2) "From 0 days to 1000 days how much longer would you invest in this relationship?", (3) "In the context of a romantic relationship (past or current), have you ever been betrayed?", and (4) "In the context of a romantic relationship (past or present), have you betrayed?". Based on Rego et al. (2016) study, four hypothetical scenarios of a relationship (A - no violence, $\mathrm{B}$ - physical violende, $\mathrm{C}$ - psychological violence or $\mathrm{D}$ - sexual violence) were presented; each participant could only pick out randomly one to answer the four questions mentioned above. Scenario A portrayed a relationship without violence:

(A) Imagine that you have been married for the past 10 years with your partner, and in the last few months you have been feeling unhappy with your relationship. For example, little things have become grounds for big discussions and you can no longer communicate with your partner. Your sex life is almost non-existent and you stay at work to delay the moment to return home. Due to your current relational situation, you feel exhausted and believe you would be happier if you were no longer in that relationship. You have made every effort to change the current situation, including talking to your partner, spending more time with him, and even surprise him even possible. During your relationship, you invested all your money on a house you bought together and you are currently living in a stable economic situation.

In this study, for scenarios $\mathrm{B}, \mathrm{C}$ and $\mathrm{D}$, one more paragraph was added to the non-violent scenario, converting it in a scenario of physical violence (B), psychological violence $(C)$ or in a scenario of sexual violence (D):

(B) There was a day, in the middle of a quarrel, your partner gave you a push and squeezed your arm, leaving you a small mark on it. ${ }^{l}$

(C) There was a day, in the middle of a quarrel, your partner after checking your cell phone without your permission, accused you, even being false, to betray him with a colleague of your work.

(D) There was a day your partner forced you to have sex, against your will, to improve your relationship. 
In all scenarios, the sunk cost effect variables were valued (great investment of money, effort and time in the relation) to obtain more reliable answers (Rego et al., 2016). In this study, the sunk cost effect is evaluated when participants choose a high value, from 0 to 100 , or a high number of days, from 0 to 1000 .

\section{Sample}

Participants $(N=267)$ were recruited via social network announcement and were asked to complete a questionnaire on an internet webpage using Google Forms software. All participants were informed about all aspects of the research, to make a free decision to voluntarily confirm their willingness to participate. To be eligible to participate in the study, participants had to be women and had to have more than 18 years old. Most women were an average age of 33 ( $S D=8.83$ years), were mothers of 1 or 2 children, with college diplomas, and were in a relationship. Participants were randomly assigned to four scenarios. There were significant differences between mean age of the participants in the non-violent scenario and all the other scenarios (for all $F$ 's, p <.05). Specifically, participants in the non-violent scenario were younger than participants in the other three scenarios. There were no age differences between participants in the other groups. Descriptive demographic information is summarized in Table 1. 


\section{Table 1}

Demographic Information

\begin{tabular}{|c|c|c|c|c|c|}
\hline Demographic with $M(\mathrm{SD})$ & $\begin{array}{c}\text { Total } \\
N=267 \\
n(\%)\end{array}$ & $\begin{array}{c}\text { Scenario A } \\
N=46 \\
n(\%)\end{array}$ & $\begin{array}{c}\text { Scenario B } \\
N=87 \\
n(\%)\end{array}$ & $\begin{array}{c}\text { Scenario } C \\
N=77 \\
n(\%)\end{array}$ & $\begin{array}{l}\text { Scenario D } \\
\quad N=57 \\
n(\%)\end{array}$ \\
\hline Age & $33.60(8.83)$ & $29.54(11.21)$ & $\begin{array}{l}35.00 \\
(7.96)\end{array}$ & $\begin{array}{l}34.10 \\
(8.59)\end{array}$ & $\begin{array}{l}34.04 \\
(7.42)\end{array}$ \\
\hline $18-20$ & $21(7.7)$ & $9(19.6)$ & $2(2.3)$ & $5(6.5)$ & $3(5.3)$ \\
\hline $21-30$ & $70(25.6)$ & $25(54.3)$ & $20(23.0)$ & $18(23.4)$ & $11(19.3)$ \\
\hline $31-40$ & $125(45.8)$ & $9(19.6)$ & $46(52.9)$ & $35(45.5))$ & $33(57.9)$ \\
\hline $41-50$ & $47(17.2)$ & $7(15.2)$ & $15(17, .2)$ & $16(20.8)$ & $9(15.8)$ \\
\hline $51-60$ & $10(3.7)$ & $2(4.3)$ & $4(4.6)$ & $1(1.3)$ & $1(1.8)$ \\
\hline \multicolumn{6}{|l|}{ Marital status } \\
\hline $\begin{array}{l}\text { Single } \\
\text { Married } \\
\text { Divorced } \\
\text { Non-marital partnership } \\
\text { Widowed }\end{array}$ & $\begin{array}{c}77(28.8) \\
122(45.7) \\
10(3.7) \\
57(21.3) \\
1(.4)\end{array}$ & $\begin{array}{c}29(63.0) \\
9(19.6) \\
2(4.3) \\
6(13.0) \\
-\end{array}$ & $\begin{array}{c}13(14.9) \\
45(51.7) \\
6(6.9) \\
22(25.3) \\
1(1.1)\end{array}$ & $\begin{array}{c}20(26.0) \\
40(51.9) \\
1(1.3) \\
16(20.8) \\
-\end{array}$ & $\begin{array}{c}15(26.3) \\
28(49.1) \\
1(1.8) \\
13(22.8) \\
-\end{array}$ \\
\hline $\begin{array}{l}\text { In a current relationship? } \\
\quad \text { Yes }\end{array}$ & $233(87.3)$ & $35(76.1)$ & $79(90.8)$ & $69(89.6)$ & $50(87.7)$ \\
\hline $\begin{array}{l}\text { No } \\
\text { With children? }\end{array}$ & $34(12.7)$ & $11(23.9)$ & $8(9.2)$ & $8(10.4)$ & $7(12.3)$ \\
\hline Yes & $190(71.2)$ & $19(41.3)$ & $73(83.9)$ & $57(74.0)$ & $41(71.9)$ \\
\hline $\begin{array}{l}\text { No } \\
\text { Highest completed education }\end{array}$ & $77(28.8)$ & $27(58.7)$ & $14(16.1)$ & $20(26.0)$ & $16(28.1)$ \\
\hline $\begin{array}{l}\text { Junior high } \\
\text { High school } \\
\text { College1-3 years }\end{array}$ & $\begin{array}{l}11(3.9) \\
52(19.5) \\
138(51.7)\end{array}$ & $\begin{array}{l}8(17.4) \\
16(34.8) \\
19(41.3)\end{array}$ & $\begin{array}{c}2(2.3) \\
8(9.2) \\
48(55.2)\end{array}$ & $\begin{array}{c}1(1.3) \\
19(24.7) \\
43(55.8)\end{array}$ & $\begin{array}{c}- \\
9(15.8) \\
28(49.1)\end{array}$ \\
\hline College Master degree & $57(21.3)$ & $2(4.3)$ & $25(28.7)$ & $11(14.3)$ & $19(33.3)$ \\
\hline College $\mathrm{PhD}$ degree & $5(1.9)$ & - & $3(3.4)$ & $1(1.3)$ & $1(1.8)$ \\
\hline $\begin{array}{l}\text { Other } \\
\text { "Have you ever been } \\
\text { betrayed?" }\end{array}$ & $4(1.5)$ & $1(2.2)$ & $1(1.1)$ & $2(2.6)$ & - \\
\hline Yes & $122(45.7)$ & $22(47.8)$ & $41(47.1)$ & $31(40.3)$ & $28(50.9)$ \\
\hline $\begin{array}{l}\text { No } \\
\text { "Have you betrayed?" }\end{array}$ & $145(54.3)$ & $24(52.2)$ & $46(52.9)$ & $46(59.7)$ & $29(49.1)$ \\
\hline $\begin{array}{l}\text { Yes } \\
\text { No }\end{array}$ & $\begin{array}{l}102(38.2) \\
165(61.8)\end{array}$ & $\begin{array}{l}14(30.4) \\
32(69.6)\end{array}$ & $\begin{array}{l}29(33.3) \\
58(66.7)\end{array}$ & $\begin{array}{l}31(40.3) \\
46(59.7)\end{array}$ & $\begin{array}{l}28(49.1) \\
29(50.9)\end{array}$ \\
\hline
\end{tabular}




\section{Analytic Strategy}

The Statistical Package for the Social Sciences (SPSS), version 25 was used to conduct each analysis. To understand the current sample, frequencies and appropriate measures of central tendency and variability were computed for all of the demographic variables.

Preliminary analyses were also conducted prior to testing the hypothesis to confirm analytic assumptions and consistency of the data with theoretical underpinnings. These analyses included Pearson's and Spearmen's correlations between sociodemographic data and sunk cost effect (ruler and days'-measures). One Way ANOVA was used to test the effect of the type of scenario (non-violent, physical violence, psychological violence, sexual violence) on sunk cost effect (for ruler and day-measures independently) and an Independent Samples t-test to evaluate the effect of relationship status on sunk cost effect (ruler and days'-measures independently). On all group, comparisons that revealed significant differences between scenarios (analysis of covariance, ANCOVA) were performed in order to control the effects of relationship status in sunk cost effect (ruler and days'-measures independently). All significance tests were two-sided and values of $p \leq 0.05$ represented significant differences.

\section{Results}

Results showed that there was no significant correlation between sunk time (in both ruler- and days'-measures) and age, $r=-.036$, n.s. and $r=-.006$, n.s., neither scholarship, $r_{s}=-$ $.029 \mathrm{n} . \mathrm{s}$. and $r_{s}=-.050$, n.s. However, results showed that there was a significant correlation between relationship status and the sunk time effect for both ruler-measure, $r=.216, p<.001$, and days-measure, $r=.236, p<.001$ (see Table 2). This means that if the participants were in a relationship, the more time/days they were willing to invest in that relationship.

\section{Table 2}

Correlations between sunk effect measures and sociodemographic variables

\begin{tabular}{lll}
\hline & Sunk Effect & Sunk Effect \\
& Ruler measure & Days measure \\
\hline Age & -.036 & -.006 \\
Scholarship & -.029 & -.050 \\
Relationship & $.216^{* * *}$ & $.236^{* * *}$ \\
status & & \\
\hline
\end{tabular}

ANOVA results showed a significant effect of scenario on sunk time effect, in both ruler-measure, $F(3,263)=3.98, p=.008, \eta_{\mathrm{p}}{ }^{2}=.043$, and days-measure, $F(3,263)=3.82, p$ $=.010, \eta_{\mathrm{p}}^{2}=.042$ (see Table 3 ). At the same time, there was found a significant effect of relationship status (being vs. not being in a relationship) on sunk time effect, in both rulermeasure, $t(265)=3.44, p=.001, d=0.67$, and days-measure, $t(56)=3.77, p<.001, d=0.78$ (see Table 4). Levene's test for days-measure indicated unequal variances $(F=16.99, p<.001)$, so degrees of freedom were adjusted from 265 to 55 . Women in a relationship were willing to invest more time $(M=51.7, S D=34.7)$ and days $(M=434.7, S D=381.6)$ in that relationship, compared to single women (ruler-measure $M=30.18, S D=28.8$; days-measure $M=179.3, S D$ $=263.4$ ), regardless of the assigned scenario. 
Table 3

Differences between scenarios in sunk time effect

\begin{tabular}{lllll}
\hline Scenario & $\mathrm{n}$ & $\mathrm{M}(\mathrm{SD})$ & $\mathrm{F}$ & $\mathrm{p}$-value \\
\hline Time Measure & & & & \\
$\quad$ Without violence & 46 & $54.15(35.44)$ & & \\
Physical violence & 87 & $44.64(34.14)$ & 3.98 & .008 \\
$\quad$ Psychological violence & 77 & $57.77(33.94)$ & & \\
$\quad$ Sexual violence & 57 & $39.47(33.54)$ & & \\
& & & & \\
Ruler Measure & & & & \\
$\quad$ Without violence & 46 & $483.63(410.60)$ & & .010 \\
$\quad$ Physical violence & 87 & $345.00(372.97)$ & 3.82 & \\
$\quad$ Psychological violence & 77 & $485.21(374.54)$ & & \\
$\quad$ Sexual violence & 57 & $311.60(333.12)$ & & \\
\hline
\end{tabular}

Table 4

Differences between relationship status in sunk time effect

\begin{tabular}{lllll}
\hline Scenario & $\mathrm{n}$ & $\mathrm{M}(\mathrm{SD})$ & $\mathrm{t}$ & $\mathrm{p}$-value \\
\hline Time Measure & 34 & $30.18(28.80)$ & & \\
$\quad$ Single & 233 & $51.70(34.75)$ & 3.44 & .001 \\
$\quad$ In a relationship & & & & \\
& & & & \\
Ruler Measure & 34 & $179.29(263.41)$ & 3.77 & .000 \\
$\quad$ Single & 233 & $434.71(381.63)$ & & \\
$\quad$ In a relationship & & & & \\
\hline
\end{tabular}

After controlling the effect of relationship status, there was still a significant effect of type of scenario on sunk time effect in both ruler-measure, $F(3,262)=4.64, p=.004, \eta_{\mathrm{p}}{ }^{2}=$ .040 , and days-measure, $F(3,262)=4.83, p=.003, \eta_{\mathrm{p}}{ }^{2}=.052$.

For ruler-measure (see Figure 1), Bonferroni corrected post hoc analysis found that women would spend more time in a scenario of psychological violence than in a scenario of sexual violence $(p=.015)$ and in a scenario of physical violence $(p=.065)$. On the other hand, women in a non-violent scenario would tend to spend more time in the relationship than those exposed to a scenario of sexual violence $(p=.058)$. 
Figure 1. Sunk Time Effect for ruler-measure (being 0 - no time, 100 - very long) in the four conditions (non-violent scenario, scenario of physical violence, scenario of psychological violence, scenario of sexual violence). Error bars represent standard errors of the mean. $* p<$ $.05 ; \top p<.10$

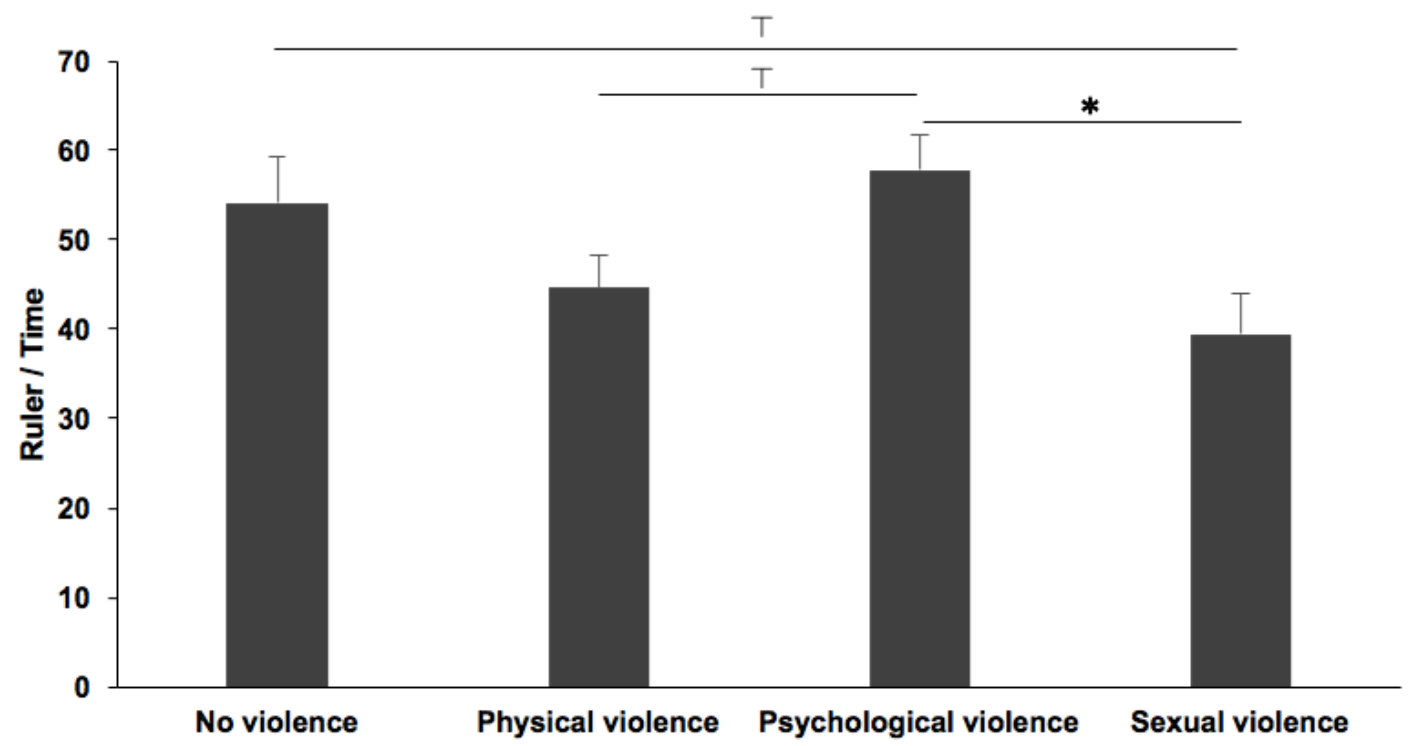

For days-measure (see Figure 2), Bonferroni corrected post hoc analysis found women would spend more days in a scenario of psychological violence than in a scenario of sexual violence $(p=.049)$ and in a scenario of physical violence $(p=.070)$. On the other hand, women in a non-violent scenario spent significantly more days in the relationship than those exposed to a scenario of sexual violence $(p=.029)$ or physical violence $(p=.045)$. 
Figure 2. Sunk Time Effect for days-measure (being 0 - 0 days, $1000-1000$ days) in the four conditions (non-violent scenario, scenario of physical violence, scenario of psychological violence, scenario of sexual violence). Error bars represent standard errors of the mean. ${ }^{*} p<$ $.05 ; \top p<.10$

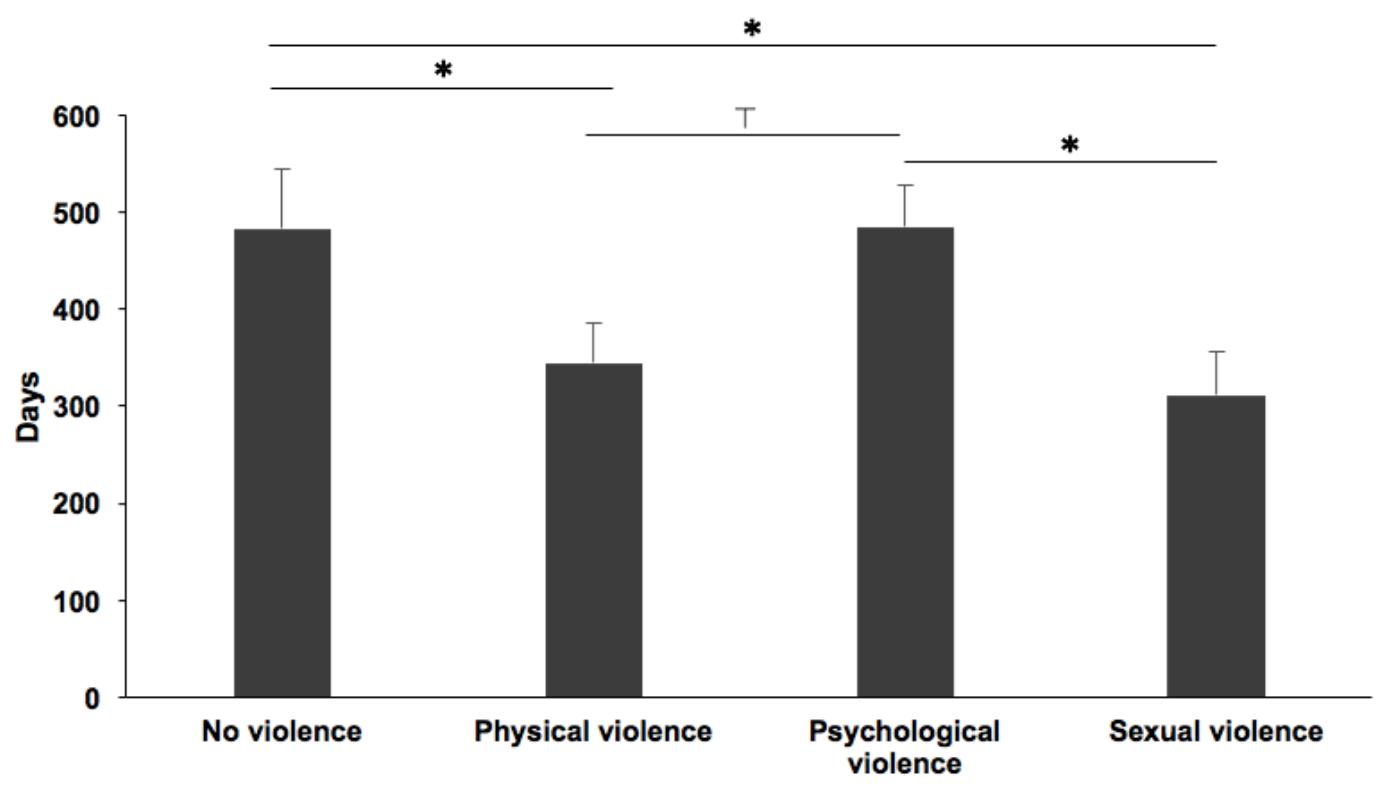

Discussion

The likelihood to stay, as well as the time one will continue to invest in an unhappy relationship, is higher when money, effort and time had been previously invested in that relationship (Rego et al., 2016). This tendency to considerer prior investments of money, effort or time as a motivation to a continuous investment in a failed direction, when the logical action would be to stop investing, is known as sunk (cost/time) effect. The main purpose of the present study was to understand if whether the resistance to change diminuishes, in a context of a relationship with previous investment of time, effort and money, when abusive behaviors are involved. To accomplish this aim, women participants read one of four hypothetical scenarios representing an unhappy relationship (one without violence, or one with one episode of physical violence, or one with one episode of psychological violence or one with one episode of sexual violence) and had to decide how much time they would be willing to stay in that relationship, in which they had made prior investments (either in terms of effort, money and time). Evidence for a sunk cost effect would be participants allocating more time in a relationship.

Results showed a significant effect of relationship scenario (without violence, with physical violence, with psychological violence or with sexual violence) on sunk time effect, in both ruler-measure and days-measure. In a non-violent scenario, women tend to spend more time in the relationship than those exposed to a scenario of sexual violence or to a scenario of physical violence. In other words, prior (monetary, time and effort) investments in a relationship will not produce sunk cost effect when there is physical or sexual violence. According to the interdependence theory (Kelley \& Thibaut, 1978), the motivation to maintain a relationship is a result of the benefits that come from the relationship outweighing its costs combined with poor alternatives in the environment (Rusbult \& Buunk, 1993). In this sense, to leave a relationship, there should be a lack of alternatives to it and costs might need to outweigh the sum of all benefits the relationship could offer. According to Choua and Hsub (2018) people perceived that benefits occur when they outweigh costs and perceived investment when investment (sunk) costs outweigh benefits. In this perspective, it is possible that present findings mean physical and sexual violence were assumed by women as not tolerable behaviors ('costs') and outweigh prior investments to the relationship. Research has shown generalized disapproval of physical and sexual violence in intimate relationships (e.g. Copp, Giordano, Longmore, \& Manning, 
2016; Machado, Caridade, \& Martins, 2010; Machado, Martins \& Caridade, 2014) what could explain, partially, the non-denial of the abusive nature and impact of such acts. In fact, Copp and colleagues (2016) showed that expressions of disapproval from friends and parents are related to breaking up with a partner. Also, Labella and Masten (2018) stated that disapproval of violence predicted less self-reported violence. Our results must, however, be interpreted carefully. According to expectancy-value models such as the theory of reasoned action (Fishbein \& Ajzen, 1975), attitudes toward the behavior would influence behavior through their influence on intention to engage in a behavior. Although physical and sexual violent acts were not able to produce sunk effect, and therefore, reduce time invested in a relationship with previous investments (being hypothetically associated to negative attitudes toward physical and sexual violence), it does not mean those women were able to no willing in a physical or sexual abusive relationship in a real context. The decision-making scenario of willing or leave an abusive relationship could be more complex once the perceived consequences of the behavior and the subjective probabilities one attaches to these consequences might also be consider during this process (Eagly \& Chaiken, 1998). There are several empirical studies stressing the incongruence between the high levels of abusive relationships and the expressed low levels of support for the use of violence in intimate relationships (eg. Machado et al., 2010; Sears et al. 2006).

On the other hand, there were found no significant differences for both ruler and daymeasures between non-violent and psychologically violent scenarios. Women were willing to invest the same time in a relationship without violence and in a relationship with psychological violence. In other words, the tendency participants showed to remain in a relationship with psychological violence is statistically the same to remain in a relationship without violence, when prior investments of time, effort and money were made. Furthermore, women spend more time in a scenario of psychological violence than in a scenario of sexual violence or of physical violence. Relationship factors, such as the duration and intensity of the relationship, have been pointed to increase the risk of returning to an abusive relationship (Rusbult \& Martz, 1995), as well as having limited resources for economic independence (Jacobson and Gottman, 1998). According to present findings, contrary to physical and sexual violence, it is possible psychological violence was not assumed as sufficient 'cost' to outweigh previous investments and therefore, leave a relationship (Rusbult \& Buunk, 1993). While there is a generalized disapproval of violence in the context of relationships (e.g. Machado, Gonçalves, Matos, \& Dias, 2007), the presence of some forms of violent behaviors in some circunstances seems also to be accepted (Nava-Reyes, Rojas-Solís, Amador, \& Quintero, 2018; Sears et al. 2006). In fact, psychological abuse was significantly reported more than physical abuse (Mills, Hill, \& Johnson, 2017). Acts of "lesser" violence (e.g., throwing objects, insulting or humiliating, yelling or threatening to cause fear) are usually more reported in several studies (Machado, Matos, \& Moreira, 2003; Machado et al., 2010). Empirical studies also found out that 25-35\% of the adolescents interpret violence in some situations as a manifestation of love (Glass et al. 2003; Henton et al. 1983). Machado, Caridade, and Martins (2010), in a study carried out with a sample of 4,667 participants aged 13 to 29 years, observed victims expressed higher support for violence than non-victims both in the case of general violence and physical violence, but no differences between victims and non-victims of emotional violence were found in terms of abusive beliefs.

Regarding the effect of relationship status and sunk effect, the results showed that if the participants were in a relationship, the more time/days they were willing to invest in that relationship, independently of the scenario. These results suggest that being in a relationship could enhance the likelihood of committing the sunk cost effect in the context of intimate relationships; prior investments in a relationship might acquire more value for those individuals in a current relationship where those efforts exist naturally. However, there is only one study (Rego et al., 2016) where sunk cost and relationship status where related and no association between those variables was found. On the other hand, it is important to note that in present study the number of single participants were lower compared to those in a relationship. 
Therefore, there is a call for broader and more robust studies covering the relationship between sunk cost/time effect and relationship status.

\section{Future research and Practical Implications}

Although this study shows that women spend more time in a scenario of psychological violence than in a scenario of sexual violence or of physical violence, it also shows that being in a relationship could enhance the likelihood of committing the sunk cost effect in the context of intimate relationships; that is, violent relationships can perpetuate themselves due to this effect. Attitudes towards men's violence against women determines the perpetration of violence against women and its responses by the victim and others around her (Flood \& Pease, 2009). Therefore, attitudes are the target of violence prevention campaigns. Awareness raising for the identification and refusal of violence against women implies recognizing less explicit forms of violence (specially psychological violence) and their consequences. If one considers that psychological violence is less serious than physical or sexual violence (although highly correlated) we are aceppting that there is a type of violence tolerated socially and individually. Therefore, future research and social workers should focus on developing violence prevention programs knowledge-based on the factors that lead to remaining violent relationships, specially on 'less violent scenarios' as psychological violent relationships. 


\section{References}

Ali, M., Zhou, L., Miller, L., \& Ieromonachou, P. (2016). User resistance in IT: A literature review. International Journal of Information Management, 36(1), 35-43.

Arkes, H. R., \& Ayton, P. (1999). The sunk cost and Concorde effects: are humans less rational than lower animals? Psychological Bulletin, 125, 591 -600. https://doi.org/10.1037/0033-2909.125.5.591

Benson, B. (2017). Cognitive bias cheat sheet, simplified. https://betterhumans.coach.me/cognitive-bias-cheat-sheet55a472476b18.

Bermea, A. M., Khaw, L., Hardesty, J. L., Rosenbloom, L., \& Salerno, C. (2017). Mental and Active Preparation: Examining Variations in Women's Processes of Preparing to Leave Abusive Relationships. Journal of interpersonal violence. https://doi.org/ 10.1177/0886260517692332

Buchko, A. A., Buscher, C., \& Buchko, K. J. (2017). Why do good employees stay in bad organizations?. Business Horizons, 60(5), 729-739. https://doi.org/10.1016/j.bushor.2017.06.001.

Centers for Disease Control and Prevention. (2018). Intimate partner violence. Retrieved from https://www.cdc.gov/violenceprevention/intimatepartnerviolence/index.html.

Chou, S. W., \& Hsu, C. S. (2018). An empirical investigation on knowledge use in virtual communities-A relationship development perspective. International Journal of Information Management, 38(1), 243-255. https://doi.org/10.1016/j.ijinfomgt.2017.10.003

Chung, S. H., \& Cheng, K. C. (2018). How does cognitive dissonance influence the sunk cost effect?. Psychology research and behavior management, 11, 37. https://doi.org/10.2147/PRBM.S150494.

Chung, G. H., Choi, J. N., \& Du, J. (2017). Tired of innovations? Learned helplessness and fatigue in the context of continuous streams of innovation implementation. Journal of Organizational Behavior, 38(7), 1130-1148. https://doi.org/10.1002/job.2191.

Copp, J. E., Giordano, P. C., Longmore, M. A., \& Manning, W. D. (2016). The development of attitudes toward intimate partner violence: An examination of key correlates among a sample of young adults. Journal of interpersonal violence. https://doi.org/0886260516651311.

Council of Europe (2011). Explanatory Report to the Council of Europe Convention on Preventing and Combating Violence against Women and Domestic Violence. Council of Europe Treaty Series No 210.

De Ridder, D. T., \& Lensvelt-Mulders, G. (2018). Taking stock of self-control: A metaanalysis of how trait self-control relates to a wide range of behaviors. In SelfRegulation and Self-Control (pp. 221-274). Routledge.

Eagly, A. H., \& Chaiken, S. (1998). Attitude structure and function. In D. T. Gilbert, S. T. Fiske, \& G. Lindzey (Eds.), The handbook of social psychology (pp. 269-322). New York, NY, US: McGraw-Hill.

Feldman, G., \& Wong, K. F. E. (2018). When action-inaction framing leads to higher escalation of commitment: A new inaction-effect perspective on the sunk-cost fallacy. Psychological science, 29(4), 537-548.

Fishbein, M., \& Ajzen, I. (1975). Belief, attitude, intention, and behavior: An introduction to theory and research. Boston: Addison-Wesley. 
Flood, M., \& Pease, B. (2009). Factors influencing attitudes to violence against women. Trauma, violence, \& abuse, 10(2), 125-142. https://doi.org/ $10.1177 / 1524838009334131$

Glass, N., Fredland, N., Campbell, J., Yonas, M., Sharps, P., \& Kub, J. (2003). Adolescent dating violence: Prevalence, risk factors, health outcomes, and implications for clinical practice. JOGNN Clinical Issues, 32, 227-238. https://doi.org/10.1177/0884217503252033.

Haita-Falah, C. (2017). Sunk-cost fallacy and cognitive ability in individual decisionmaking. Journal of Economic Psychology, 58, 44-59. doi.org/10.1016/j.joep.2016.12.001.

Heintz, C., Celse, J., Giardini, F., \& Data, S. M. (2015). Facing expectations: Those that we prefer to fulfiland those that we disregard. Judgment and Decision Making, 10(5), 442. Available online at: https://www.sjdm.org/15/15204/jdm15204.pdf

Henton, J., Cate, R., Koval, J., Lloyd, S., \& Christopher, S. (1983). Romance and violence in dating relationships. Journal of Family Issues, 4, 467-482. https://doi.org/10.1177/019251383004003004

Jacobson, N., \& Gottman, J. (1998). When men batter women: New insights into ending abusive relationships. New York: Simon \& Schuster

Kahneman, D., \& Tversky, A. (1979). Prospect theory: an analysis of decisions under risk. Econometrica, 47(2), 263-292. https://doi.org/10.2307/1914185

Kahneman, D., \& Tversky, A. (1984). Choices, values, and frames. American Psychologist, 39, 341-350. https://doi.org/10.1037/0003-066 X.39.4.341

Keeling, J., Smith, D., \& Fisher, C. (2016). A qualitative study exploring midlife women's stages of change from domestic violence towards freedom. $B M C$ Women's Health, 16, Article 13. https://doi.org/10.1186/s12905-016-0291-9

Khaw, L., \& Hardesty, J. L. (2015). Perceptions of boundary ambiguity in the process of leaving an abusive partner. Family Process, 54, 327-343. https://doi.org/10.1111/famp.12104

Kim, S. S., \& Son, J. Y. (2009). Out of dedication or constraint? A dual model of postadoption phenomena and its empirical test in the context of online services. MIS Quarterly, 33(1), 49-70. https://doi.org/10.2307/20650278

Khoso, I., Shaikh, M., Parmar, V., \& Bashir, A. (2018). Escalating Behavior To Losing Projects: Agency Theory Perspective. Grassroots, 48(1).

Labella, M. H., \& Masten, A. S. (2018). Family influences on the development of aggression and violence. Current opinion in psychology, 19, 11-16. https://doi.org/10.1016/j.copsyc.2017.03.028

Lacey, K. K., Saunders, D. G., \& Zhang, L. (2011). A comparison of women of color and non-Hispanic White women on factors related to leaving a violent relationship. Journal of Interpersonal Violence, 26, 1036-1055. https://doi.org/10.1177/0886260510376496

Leahy, R. L. (2000). Sunk costs and resistance to change. Journal of Cognitive Psychotherapy, 14(4), 355-372.

Lee, J. S., Keil, M., \& Wong, K. F. E. (2018). Does a Tired Mind Help Avoid a Decision Bias? The Effect of Ego Depletion on Escalation of Commitment. Applied Psychology, 67(1), 171-185. https://doi.org/10.1111/apps.12109.

Liao, W., McComas, K. A., \& Connie Yuan, Y. (2017). The Influence of Unrestricted Information Exchange on Willingness to Share Information With Outsiders. Human Communication Research, 43(2), 256-275. https://doi.org/ 10.1111/hcre.12104. 
Lin, Y. C., \& Chang, C. C. A. (2017). Exploring wasteful consumption. Journal of Environmental Psychology, 49, 106-111. https://doi.org/10.1016/j.jenvp.2017.01.001.

Löckenhoff, C. E. (2018). Aging and Decision-Making: A Conceptual Framework for Future Research-A Mini-Review. Gerontology, 64(2). https://doi.org/10.1159/000485247

Machado, C., Caridade, S., \& Martins, C. (2010). Violence in juvenile dating relationships self-reported prevalence and attitudes in a Portuguese sample. Journal of Family Violence, 25(1), 43. https://doi.org/10.1007/s10896009-9268-X

Machado, C., Gonçalves, M., Matos, M., \& Dias, A. R. (2007). Child and partner abuse: Self-reported prevalence and attitudes in the north of Portugal. Child Abuse \& Neglect, 31(6), 657-670. https://doi.org/10.1016/j.chiabu.2006.11.002

Machado, C., Martins, C., \& Caridade, S. (2014). Violence in intimate relationships: A comparison between married and dating couples. Journal of Criminology, 2014. https://doi.org/10.1155/2014/897093

Machado, C., Matos, M., \& Moreira, A. I. (2003). Violência nas relações amorosas: Comportamentos e atitudes na população universitária. Psychologica, 33, 69-83.

Mills, C. P., Hill, H. M., \& Johnson, J. A. (2018). Mediated Effects of Coping on Mental Health Outcomes of African American Women Exposed to Physical and Psychological Abuse. Violence against women. https://doi.org/10.1177/1077801216686219

Nava-Reyes, M. A., Rojas-Solís, J. L., Amador, L. M. G., \& Quintero, L. A. M. (2018). Gender roles, sexism and myths of romantic love in Mexican adolescents. Interamerican Journal of Psychology, 52(1), 102-111. https://doi.org/10.30849/rip/ijp.v52i1.341

O'Mara, S. (2018). The Importance of Cognitive Biases. In A Brain for Business $-A$ Brain for Life (pp. 61-75). Palgrave Macmillan, Cham.

Pachur, T., Schulte-Mecklenbeck, M., Murphy, R. O., \& Hertwig, R. (2018). Prospect theory reflects selective allocation of attention. Journal of experimental psychology: general, 147(2), 147. https://doi.org/ 10.1037/xge0000406.

Rachlin, H. (2000). The science of self-control. Harvard University press.

Rego, S., Arantes, J., \& Magalhães, P. (2016). Is there a Sunk Cost Effect in Committed Relationships? Current Psychology, 1-12. https://doi.org/10.1007/s12144-0169529-9

Rover, S., Wuerges, A. F. E., Tomazzia, E. C., \& Borba, J. A. (2009). Sunk Costs Effect: Does Theoretical Knowledge Affects Students' Decision Process? Brazilian Business Review (English Edition), 6(3). https://doi.org/10.15728/bbr.2009.6.3.2

Rusbult, C. E., \& Buunk, B. P. (1993). Commitment processes in close relationships: An interdependence analysis. Journal of Social and Personal Relationships, 10(2), 175-204. https://doi.org/10.1177/026540759301000202

Sears, H. A., Byers, E. S., Whelan, J. J., \& Saint-Pierre, M. (2006). If it hurts you, then it is not a joke. Adolescents' ideas about girls' and boys' use and experience of abusive behavior in dating relationships. Journal of Interpersonal Violence, 21, 1191-1207. https://doi.org/10.1177/0886260506290423

Sheeran, P., \& Abraham, C. (2017). Implications of Goal Theories for the Theories of Reasoned Action and Planned Behavior. In Planned Behavior (pp. 107-128). Routledge. 
Staw, B. M., \& Ross, J. (1987). Understanding escalation situations: Antecedents, prototypes, and solutions. In B. M. Staw \& L. L. Cummings (Eds.), Research in organizational behavior, vol. 9: 39-78. Greenwich, CT: JAI Press.

Strube, M. J. (1988). The decision to leave an abusive relationship: empirical evidence and theoretical issues. Psychological bulletin, 104(2), 236. https://doi.org/10.1037/0033-2909.104.2.236

Székely, M., \& Michael, J. (2018). Investing in commitment: Persistence in a joint action is enhanced by the perception of a partner's effort. Cognition, 174, 37-42. https://doi.org/10.1016/j.cognition.2018.01.012

Tversky, A., \& Kahneman, D. (1981). The framing of decisions and the psychology of choice. Science, 211(4481), 453-458. https://doi.org/10.1126/science.7455683.

World Health Organization (2003). The WHO multi-country study on women's health and domestic violence against women. Last accessed on 2018 Feb 13. Available form: www.who.int/gender/violence/multicountry .

Yoder, C. Y., Mancha, R., \& Agrawal, N. (2014). Culture-related factors affect sunk cost bias. Behavioral Development Bulletin 19,105-118.

https://doi.org/10.1037/h0101086 